\title{
'n Voltydse skriba vir die \\ Algemene Kerkvergadering van \\ die Nederduitsch Hervormde Kerk?
}

\author{
S J Botha
}

Hervormde Teologiese Opleiding

\begin{abstract}
A full-time secretary for the General Assembly of the Nederduitsch Hervormde Kerk?

In 1986 the General Assembly of the Nederduitsch Hervormde Kerk decided to appoint a full-time secretary. This paper asks whether such an appointment is reconcilable with the principles of the presbyterial-synodal system of church government.
\end{abstract}

Prof A D Pont het ongetwyfeld as hoogleraar op beide die vakgebiede van Kerkgeskiedenis en Kerkreg betekenisvolle en uitmuntende bydraes in diens van kerk en teologie gelewer. Dit geld nie net vir die Nederduitsch Hervormde Kerk en sy teologie-beoefening in die besonder nie, maar ook vir die kerk en die teologie in die algemeen. In hierdie artikel wil 'n (oud-)student graag aan sy (oud-)hoogleraar by aftrede hulde bring en erkening gee aan die rigtinggewende invloed wat van leermeester op leerling uitgegaan het.

\section{INI JIDING;}

Die Kommissie van die Algemene Kerkvergadering het op grond van die feit dat dit duidelik geword het 'dat dit nie meer moontlik was om 'n voltydse standplaas te beman en tegelyk skriba te wees nie', die Algemene Kerkvergadering van 12-19 Mei 1986 genader met die volgende aanbeveling (NHKA 1986b: 12, 13): 
- Die skriba word telkens verkies vir 'n tydperk van 6 jaar en dien voltyds.

- Die Kommissie van die Algemene Kerkvergadering kry opdrag om die werkterrein en verantwoordelikheid van die skriba noukeurig te omskryf, ondermeer ook wat sy verhouding met die administrateur betref.

Voor die Algemene Kerkvergadering is ook die volgende advies, wat vroeër deur die Raad vir Regsadvies aan die Kommissie gegee is, gelê (NHKA 1986b:12):

Dat indien die Bepalings so verander moet word dat die skriba nie meer driejaarliks deur die Algemene Kerkvergadering verkies word nie, maar dat ' $\mathrm{n}$ voltydse skriba in sy plek aangestel word, sal die beginsel van hiërargie in die kerk ingevoer word. Dit kan die Raad geensins aanbeveel nie.

Soos die Kommissie vroeër, het die Algemene Kerkvergadering die beswaar van die Raad vir Regsadvies verbygegaan en aan die versoek gehoor gegee, met die enkele wysiging dat die tydperk van ses jaar verkort is na drie jaar. Hierdie besluit is soos volg in Bepaling 12.7 van die Kerkwet en Bepalings opgeneem: 'Die verkiesing tot skriba geld as ' $n$ benoeming in voltydse hoedanigheid en geld telkens in 'n voltydse hoedanigheid vir 'n tydperk van drie jaar.'

Die Algemene Kerkvergadering kies dus nog driejaarliks saam met die ander lede van die Kommissie van die Algemene Kerkvergadering 'n skriba. Maar, anders as die ander lede, word die skribaat 'n voltydse pos. Dit het die konsekwensie dat die dienaar van die Woord wat as skriba verkies word, sy standplaas in 'n gemeente, of sy sinodale pos, of sy teologiese doseerpos, moet ontruim om die benoeming van skriba in voltydse hoedanigheid vir drie jaar te aanvaar. Dit is in meer as een opsig 'n merkwaardige besluit.

Dat die opskrif van hierdie artikel in die vorm van 'n vraag is, is uitdrukking daarvan dat die kerkregtelike verdedigbaarheid van hierdie besluit deur' $n$ hervormde kerk, ernstig bevraagteken word. Die woord 'hervormde' in die naam van die Nederduitsch Hervormde Kerk (hierna die NHKA) impliseer immers dat in hierdie kerk die presbiteriaal-sinodale kerkbegrip en kerkordelike sisteem gehandhaaf wil word. En juis vanuit die beginsels van hierdie kerkordelike sisteem word dit betwyfel of die besluit van die Algemene Kerkvergadering verdedigbaar is.

Tog is daar ook begrip vir die problematiek wat tot die besluit aanleiding gegee het. Daarom sal ook besin word oor ander moontlikhede om die problematiek te oorkom wat wel versoenbaar is met die beginsels van die presbiteriaal-sinodale kerkreg.

In die lig hiervan sal nou eers gekyk word na enkele ter sake beginsels van die presbiteriaal-sinodale sisteem en daarna na die funksionering van die skriba in hier- 
die sisteem. Hier sal veral aandag gegee word aan hoe dit in die vroeë Nederlandse Hervormde kerkordes neerslag gevind het met die Dordtse Kerkorde van 1619 as afsnypunt. Hoewel die Dordtse Kerkorde nie verabsoluteer word as die kanonieke formulering van die sisteem nie, is dit tog waar dat die Dordtse Kerkorde iets soos ' $n$ klassieke formulering is waar aan die presbiteriaal-sinodale sisteem in Nederland finaal vorm gegee is (Van Wyk 1989:86-87). Vervolgens sal die tradisie rondom die skriba in die NHKA nagegaan word. Dit behoort dan ' $n$ konklusie oor die kerkregtelike regverdigbaarheid al dan nie van 'n voltydse skriba in die Kerk moontlik te maak, asook die gegewens te lewer om te kan besin oor ' $n$ ander moontlike oplossing vir die problematiek wat tot die aanwys van 'n voltydse skriba gelei het.

\section{ENKELE BELANGRIKE BEGINSELS VAN DIE PRESBITERIAAL-SINODA- LE KERKLIKE ORDE}

Hierdie kerkordelike sisteem, wat teruggaan op die kerkordenende werk van Johannes Calvyn, pretendeer om Skriftuurlik en belydenisskrifmatig te wees (Pont 1977: 77-90). Dit impliseer dat daar 'n organiese verband bestaan tussen Skrif, belydenisskrif en kerkorde.

Die grondliggende uitgangspunt van hierdie orde is dat Jesus Christus self die kerk - wat sy liggaam is - regeer. Jesus Christus as Hoof en Heer van die kerk is die enigste wat gesag oor en in die kerk het. Daar is dus net een gesagsdraer of regeerder in die kerk en dit is Jesus Christus (Pont 1982b:106-107). Direk of onmiddellik regeer Hy dan die kerk deur sy Woord en Gees en indirek of middellik deur die ampte (Pont 1981:192).

Die middellike of indirekte regering deur die ampte is egter slegs moontlik as die ampte self ook onmiddellik deur die Woord en Gees, dit wil sê deur Jesus Christus self regeer word. Daarom is die gesag van die amp altyd ' $n$ afgeleide gesag. Die amp het nie eie gesag nie maar het net gesag vir sover dit aan Christus gehoorsaam is (Pont 1981:197).

Die amp is ook nooit 'n officium of hoë posisie in die kerk nie, maar 'n ministe. rium of ' $n$ dienswerk. In die naam van Christus en in gehoorsaamheid aan sy Woord word dienswerk verrig.

Die indirekte regering van die kerk deur die ampte beteken nie dat elke individuele ampsdraer los van die ander alleen of monargaal regeer nie, maar wanneer die ample in vergadering saamkom, neem hulle so deel aan die regering van die kerk deur Christus' (Pont 1981:220; vgl 1982b:110).

Dit is juis daarom dat die Nederlandse Geloofsbelydenis in Artikel 30, van die kerkraad, dit wil se die ampte-in-vergadering, set: 
Deur hierdie middel moet hulle sorg dra dat die ware godsdiens onderhou, die ware leer oral versprei, die oortreders op geestelike wyse vermaan en in toom gehou en dat ook die armes en beproefdes volgens hulle nood gehelp en getroos word.

In die woorde van Van Wyk (1989:355) kan wat tot dusver gesê is, soos volg saamgevat word:

Die presbiteriaal-sinodale kerkbegrip behels dat Jesus Christus die enigste Hoof en Heer van die kerk is. Hy regeer die kerk onmiddellik deur Woord en Gees en middellik deur die ampte wat ter vergadering byeenkom om ordelik te besin oor hoe die werk van die kerk gedoen moet word.

Die begrip 'presbiteriaal-sinodaal' is juis bedoel om die regering deur die ampte-invergadering tot uitdrukking te bring. Hoewel die ouderlingsamp as die basiese amp beskou kan word (Pont 1981:199), dui die woord 'presbiteriaal' op al die ampte wat in die reformatoriese kerk erken word. Net so dui 'sinodale' ook nie daarop dat 'n sinodale vergadering die enigste is wat in hierdie stelsel bestaansreg het nie, maar dit dui wel deeglik na elke vergadering waar die ampte in aksie is wat van die plaaslike kerkraad af breër uitloop tot by die sinode (Van Wyk 1989:115-116). 'Presbiteriaal-sinodaal' beteken dus presies dieselfde as ampte-in-vergadering.

Dit is tog ook belangrik om te beklemtoon dat dit hier gaan om die vergadering van die ampte en nie van die ampsdraers nie. Die amp het wel 'n afgeleide of betreklike gesag wat van Christus ontvang is en hierdie gesag word in vergadering uitgeoefen. Die vergadering het dus nie statutère gesag nie, maar wel die gesamentlike gesag van die vergaderde ampte. Terselfdertyd moet onthou word dat die amp die betreklike gesag dra en nie die mens wat in die amp staan - die ampsdraer - nie (Pont 1982b:110).

Waar die amp in hierdie stelsel 'n ministerium of dienswerk is en nie 'n officium of hooggeplaasde posisie nie, kan daar hoegenaamd geen sprake wees van 'n hiërargie van die een amp oor die ander, of van die een ampsdraer oor die ander ampsdraer nie. Om dieselfde rede is die een gemeente nie hoër as die ander gemeente of een vergadering van die ampte hoër as die ander nie. Daarom kan daar ook nie van enige hiërargie sprake wees tussen die vier vergaderings wat normaalweg in hierdie stelsel onderskei word nie, naamlik die kerkraad, die klassis, die provinsiale of partikuliere en die nasionale sinode. Dit gaan nie om laere en hoëre vergaderings nie, want prinsipieël is daar geen verskil in gesag nie. Ter onderskeiding word wel van ' $n$ mindere en ' $n$ meerdere vergadering gepraat. Daar is nie ' $n$ kwalitatiewe verskil tussen mindere en meerdere vergaderings nie, maar slegs 'n kwantitatiewe 
verskil (Van Wyk 1989:104). Beide staan onder die onmiddellike gesag van Jesus Christus wat sy kerk deur sy Woord en Gees regeer.

Hieruit is die baie sterk beklemtoning van die anti-hiërargiese beginsel in die presbiteriaal-sinodale kerklike ordes volkome begryplik. Natuurlik het die reformatoriese vadere met die anti-hiërargiese beginsel veral ook sterk standpunt ingeneem teen die hiërargie van die Rooms-papale sisteem. Feit is dat hulle ampsopvatting, wat sorgvuldig uit die Skrif afgelei en opgebou is, hulle tot die sterk anti-hiërargiese beginsel gelei het - daarom dat hierdie anti-hiërargiese beginsel vanaf die vroegste tye in die Nederlandse kerkordes aangetref word. So is dit in die Kerkorde van Emden (1571) wat die eerste kerkorde vir die hele Nederlandse Hervormde Kerk was, in die heel eerste artikel gestel (Pont 1981:103):

Geen kerk zal over een andere kerk, geen dienaar des Woords, geen ouderling noch diaken, zal de een over de ander heerschappij voeren, maar een iegelijk zal zich voor alle suspieciën, en aanlokking om te heerschappen wachten.

In die Dordtse Kerkorde is hierdie beginsel in artikel 84 verwoord (Pont 1981:186):

Heerschappij: Geene kerk zal over andere kerken, geen dienaar over andere dienaren, geen ouderling of diaken over andere ouderlingen en diakenen eenige heerschappij voeren.

Hand aan hand met die anti-hiërargiese beginsel het die rotasie-beginsel, wat ook in hierdie sisteem 'n prominente plek inneem, gegaan. So het Artikel 27 van die Dordtse Kerkorde ten opsigte van die ouderlinge en diakens bepaal (Pont 1981: 179):

Twee jaren dienen. De ouderlingen en diakenen zullen twee jaar dienen, en alle jaar zal het halve deel veranderd, en anderen in de plaats gesteld worden, ten ware dat de gelegenheid en de profijt van eenige kerken anders vereischt.

Die ampte van ouderling en diaken is dus nie as ampte gesien wat lewenslank deur die ampsdraers beklee moes word nie. Persone kon weer gekies word, mits daar eers 'n onderbreking in sy dienstyd gekom het. Selfs die geringste gedagte aan hiërargie, wat moontlik deur lang aaneenlopende diensjare kon ontstaan, moes afgesny word. Waar ten opsigte van die amp van dienaar van die Woord geoordeel is dat dit lewenslank en dan bowendien normaalweg lewenslank in dieselfde gemeente (Pont 1981:202) is, is die rotasiereëlings getref dat hy byvoorbeeld nie twee keer na mekaar as voorsitter van 'n meerdere vergadering gekies of aangewys mag word nie. 
Artikel 41 van die Dordtse Kerkorde het daarom ten opsigte van die klassis onder andere bepaal (Pont 1981:180):

...in welke samekomsten de dienaars bij gebeurte, of anderzins die van dezelve vergadering verkoren wordt, presideeren zullen, zoo nochtans, dat dezelfde tweemaal achtereen niet zal mogen verkoren worden.

As bedink word dat in sommige gevalle dit gebruik was dat die voorsitterskap by toerbeurt, byvoorbeeld volgens alfabetiese orde, gewissel het, dan word nog duideliker hoe daarteen gewaak is dat slegs enkele dienaars voortdurend die voorsitterstoel sou inneem.

Die anti-hiërargiese beginsel, versterk deur die rotasie-beginsel, is heeltemal begryplik teen die agtergrond van die dwingelandy van die Rooms-papale hiërargiese stelsel. Tog is dit vir die kerk vandag van net so 'n fundamentele belang. Tereg sê Van Wyk (1989:90): 'Hierdie beginsels bevestig die alleenheerskappy van Christus oor sy kerk en beklemtoon dat daar in die reformatoriese kerk nie ruimte is vir ampsdraers wat onder die indruk verkeer dat hulle met hulle besondere gawes vir die kerk onmisbaar is nie.'

Dit is ook van besondere belang om te beklemtoon dat in hierdie kerklike orde die verkondiging van die Woord die sentrale plek inneem. Hierdie verkondiging vind op sy beurt primêr plaas in die gemeente wat die plaaslike en normale verskyningsvorm van die kerk is (Pont 1981:221; vgl NHKA 1989: Art 2). Dit is waar die prediking, bediening van die sakramente, kategese, pastoraat en so meer, plaasvind.

Hieruit volg dan dat die plaaslike gemeente die normale aangewese plek is waar die ampte in aksie is. Hier vergader die basiese vergadering, naamlik die kerkraad, waar die ampte byeenkom om die kerk te regeer soos in Artikel 30 van die Nederlandse Geloofsbelydenis gestel word. Hier het dus ook die dienaar van die Woord of die lerende ouderling wat die opdrag het om te preek en te onderrig, dit is die predikant, primêr sy werkkring (Pont 1981:196). Tereg stel Van Wyk (1989:4):

Die normale verskyningsvorm van die bedienaar van die Woord is die gemeentepredikant. Die moontlikheid dat die predikant sonder 'n vaste werkkring sy dienswerk kan verrig bestaan nie omdat die amp nie 'n status of 'n gesagsposisie is nie maar 'n dienswerk. ' $n$ Dienswerk kan nie in 'n lugleegte gedoen word nie maar in 'n vaste werkkring. Die kerk werk dus met 'n funksionele ampsbeskouing omdat die dienaar geen status in homself in eie persoon besit of omdat hy 'n opgeleide persoon is nie, maar omdat hy toegelaat is om die Woord te verkondig binne ' $n$ vaste werkkring. 
Uit die funksionele ampsbeskouing volg dat iemand slegs die amp kan beklee solank hy die ampswerk doen. Omdat die amp 'n ministerium is en nie 'n officium nie, verval die amp in beginsel as die dienaar nie meer die ampswerk doen nie (Pont 1981:201).

Juis in die plaaslike gemeente waar die predikant as dienaar van die Woord die funksies van die amp vervul, het hy ook deel aan die basiese regeervergadering van die presbiteriaal-sinodale kerklike orde, naamlik die kerkraad (Pont 1981:200). Saam met die ouderlinge regeer hy die kerk as hulle in die kerkraad byeenkom. Van hier af kan hy dan op 'n meerdere regeervergadering sitting neem as hy deur die kerkraad afgevaardig word. Trouens, in hierdie kerklike orde is die amp en afvaardiging deur die mindere vergadering voorwaardes vir sitting op die meerdere vergadering (Pont 1981:229; Van Wyk 1989:106).

\section{DIE SKRIBA VAN 'N MEERDERE VERGADERING IN HIERDIE SIS- TEEM}

Binne die omraming wat hierdie beginsels bied, het die skriba van elke vergadering ook sy plek gevind. Soos die voorsitter was die skriba ook op elkeen van die vergaderings in hierdie orde ' $n$ vaste funksionaris, maar dan ' $n$ funksionaris met ' $n$ vaste omskrewe taak wat verval het sodra die vergadering sy werk afgehandel en ontbind het. Vanaf die begin word bepalings rondom die skriba in die vroeë Nederlandse kerkordes gevind. In Artikel 24 van die Acta van die Nasionale Sinode van Dordt (1578) is bepaal:

In alle kerken zal een boek zijn, in het welk naarstiglijk en getrouwelijk de handelingen die in de kerkraad besloten en met algemene bewilliging der optekening waardig geacht zijn, opgeshreven zullen worden, dewelke men, ter naaster verzameling, telken reize oplezen zal, opdat men niets vergete in het werk te stellen.

(Pont 1981:134)

Dit gaan in hierdie besluit oor die handelinge van die plaaslike kerkraad. Hoewel nie uitdruklik genoem nie, is dit tog duidelik dat iemand aangewys moes wees om die handelinge te kon opskryf. Dit is interessant dat die funksionaris glad nie genoem word nie, maar slegs die werk wat gedoen moes word. Die implikasie is wel duidelik dat die funksie wat vervul moes word belangriker was as die funksionaris. Die kerkraad se besluite was die bepalende saak. Dit moes ywerig en noukeurig opgeskryf en ook deur die deelnemers goedgekeur word as 'n korrekte optekening. By later geleentheid moes dit dan weer dien om te sien hoe tevore gehandel is en of alle besluite wel uitgevoer is. Daarin het die kontinuiteit ook gelê. 
Rondom die persoon van die skriba kon hoogstens die afleiding gemaak word dat hy verkieslik iemand moes wees wat die vermoë en bekwaamheid gehad het om alles wat werd was om opgeteken te word, ywerig en noukeurig te kon opteken.

Of vir elke afsonderlike sitting van die kerkraad, wat in baie gevalle weekliks was (Art 6, Acta van Emden 1571, in Pont 1981:103), telkens 'n ander ampsdraer as skriba aangewys is, word nie gesè nie. Wat hier in gedagte gehou moet word, is dat die kerkraad as die primêre vergadering van die ampte voortdurend in sitting was en nie soos die meerdere vergaderings, nadat die werksaamhede afgehandel is, uiteengegaan en opgehou bestaan het nie. Die skriba sou dus wel vir meer sittings aangewys kon word. Tog sou hy vir hoogstens twee jaar aaneenlopend as skriba kon dien, omdat dit die duurte van sy dienswerk as ouderling was.

Artikel 31 van die Acta van die provinsiale sinode van Zeeland 1591 bepaal (Reitsma \& Van Veen 1896:22):

In deze tweederleij tesamencomsten zal bij den praeses ende assessor een scriba gevoecht worden om neerstelicken op te schrijven, hetgeene weerdich is aangeteekent te zijne....

Die taak van die skriba op sinodale vlak het dus nie verskil van die taak van die skriba van die kerkraad nie. Dit wat werd was om opgeskryf te word, moes opgeteken word. In die notule of acta is opgeteken hoedat die Woord gehoorsaam is en dit het kontinuïteit gewaarborg. Daar was nie sprake van dat die kontinuiteit deur persone gewaarborg moes word nie (Pont 1982b:124). Juis daarom moes die optekening noukeurig wees en ook eers goedgekeur word.

So belangrik was die noukeurige optekening dat as geoordeel is dat dit te veel vir een persoon sou wees, selfs 'n tweede skriba aangewys is. Die Suid-Hollandse sinode van 1598 te Dordrecht het besluit (Reitsma \& Van Veen 1894:121):

Insghelijex heeft de synodus goetghevonden, dat voortaan den scribae des synodi tot sijner verlichtinghe zal bijgevoecht werden dieghene, die naest hem de meeste stemme zal hebben.

Ook toe die Suid-Hollandse sinode in 1618 te Delft vergader het, het hy sodanige besluit geneem:

De synodus heeft op het versouck des scriba hem tot medescribam bijgevoegt Gideon Sonnevelt tot sijner verlichtinge ende des te seeckerder aenteikeninge van tgene in deze vergadering gepasseert.

Soos te verstane is ook by die groot Sinode van Dordt 1618-1619 twee skribas aangewys, te wete Sebastianus Dammanius, predikant van Zutfen en Festus Hommius, predikant van Leiden (Donner \& Van den Hoorn sj:9). Dit was natuurlik 'n uitson- 
derlike sinode wat op 13 November 1618 begin het en eenhonderd en tagtig sittings later, op 29 Mei 1619, eers afgesluit is. Dit het inderdaad baie hoë eise, selfs aan twee skribas, gestel.

By 'n enkele geleentheid is die vraag wel voor 'n meerdere vergadering gelê of 'n meerdere vergadering nie ' $n$ 'gedurige scriba' kon hê nie. Dit het in 1605 gebeur by die provinsiale sinode van Noord-Holland (Reitsma \& Van Veen 1892:380-381):

Dewijle doch bij die broederen gevraecht wordt of het gerade ware, dat een gedurige scriba des sijnodi gestellt mochte worden, zoo wordt zulx tot de classes gerefereerd.

Onder 'n gedurige skriba is alleen maar verstaan dat dieselfde ampsdraer vir ' $n$ langer tydperk aaneenlopend gekies kon word. Dit het hoegenaamd nie gegaan om iemand wat dan voltyds benoem of gekies moes word nie. In die geval van die voorsitter van ' $n$ meerdere vergadering is uitdruklik bepaal dat dieselfde persoon nie twee keer na mekaar gekies kon word nie (vgl Art 41 van die Dordtse Kerkorde). Met die versoek tot ' $n$ gedurige skriba is bedoel dat die persoon nie aan dieselfde reël as die voorsitter onderwerp moes word nie.

By die volgende Noord-Hollandse sinode te Haarlem in 1606 is die antwoord van die klassisse ontvang (Reitsma \& Van Veen 1892:383):

Dewijle de voorgaende sijnodus tot de classes gerefereert heeft de vrage van een gedurige scriba, oft geraden is datter een gestelt werde, is bij het meestendeel der classen ongeraden gevonden.

So is 'n gedurige skriba, dit wil sê een wat vir meer as een sinode agtereenvolgens gekies kon word, afgewys as nie gewens nie. Die versoek is nooit herhaal by enige provinsiale of nasionale sinode nie. Daar is op dié wyse ook volstaan by die gebruik dat by die afhandeling van 'n meerdere vergadering se werksaamhede die vergadering ontbind en die funksionarisse van die bepaalde vergadering daarmee ook ophou om die onderskeie funksies te vul. Die moderamen, bestaande uit die voorsitter en skriba en soms bygestaan deur die assessor en hulpskriba, se dienstyd het dus net so lank as die sitting van die meerdere vergadering geduur. Geeneen van die meerdere vergaderings het ooit enige voortsettingskommissies gehad om tot by die volgende vergadering die funksies en verantwoordelikhede van die betrokke vergadering voort te sit nie (Bouwman 1934:87; Van Wyk 1989:286).

Hierby moet die besonder hoë frekwensie van vergaderings ook nog in gedagte gehou word. Die klassis het minstens een keer elke drie maande sitting gehad en die provinsiale sinode minstens jaarliks (Bouwman 1934:141; Van Wyk 1989:110). Dit sou beteken dat 'n predikant wat by twee agtereenvolgende vergaderings van die klassis as skriba verkies is hoogstens ses maande lank skriba sou wees. Selfs so 'n 
'geringe' uitsondering van een ampsdraer bo die ander, wou die vadere nie toelaat nie.

Twee belangrike beweegredes het hierdie houding gemotiveer: Eerstens was daar die baie sterk anti-hiërargiese beginsel wat enersyds die Christokrasie wou beklemtoon en andersyds wou verhoed dat die ampsdraer nie te veel op die voorgrond tree nie' (Van Wyk 1989:89). Die ampte was prinsipieel gelyk en daarom mag, in terme van artikel 84 van die Dordtse Kerkorde 'geen dienaar over andere dienaren...eenige heerschappij voeren' - ook nie deur as funksionaris van 'n meerdere vergadering te veel seggenskap en mag te bekom nie. Selfs die geringste sweem van enige hiërargie moes vermy word. Tweedens, voortvloeiend uit die eerste, het hulle dit nie nodig geag dat die skriba as 'n soort kontinueringsfunksionaris met regeerbevoegdhede van vergadering tot vergadering sou optree nie. Die noukeurige opgetekende notule of acta wat al die belangrike besluite van die vergadering bevat het en ook deur dieselfde vergadering bekragtig is, was genoegsame kontinuïteit en verbinding tussen vergadering en vergadering.

Ook in die Dordtse Kerkorde van 1618-1619 is 'n bepaling oor die skriba gemaak: Artikel 34 het bepaal (Pont 1981:180):

Scriba. In alle samekomsten zal bij den praeses een scriba gevoegd worden, om naarstiglijk op te schrijven, 'tgene waardig is opgeteekend de sijn.

Behalwe dat hier nou uitdruklik bepaal is dat die skriba 'n vaste funksionaris by elke vergadering sal wees, het die artikel niks nuuts bepaal nie. Wat hier saamgevat word is wat reeds tevore deur opeenvolgende sinodes bepaal is en reeds vaste gebruik in die kerk geword het. Hier word wel nogeens baie noukeurig gesâ wat die funksie van die skriba was, naamlik die ywerige en noukeurige opteken van al die sake en besluite wat werd was om opgeteken te word. Dit was dus wel 'n funksie wat 'n bepaalde onderskeidingsvermoë, bekwaamheid en presiesheid van die funksionaris vereis het. Maar dit was dan ook al wat hy moes doen. Geen verdere administratiewe verantwoordelikhede is aan hom opgedra nie.

Tog is dit interessant om daarop te let dat in Artikel 35 van die Dordtse Kerkorde (Pont 1981:180) ten opsigte van die praeses uitdruklik bepaal is: 'Voorts zal zijn ambt uitgaan, wanneer die samenkomst scheidt,' terwyl oor die skriba niks gesê word nie. Hiermee saam het Artikel 41 ook nog bepaal dat dieselfde predikant nie 'tweemaal achtereen' as praeses gekies kan word nie, terwyl so 'n bepaling nie ook oor die skriba gemaak is nie. Dit kan dalk tot die argument lei dat die Dordtse Kerkorde so die moontlikheid wou ooplaat dat die skriba kon bly funksioneer nadat 'n meerdere vergadering afgesluit is en dat terselfdertyd ook die moontlikheid oop- 
gelaat word dat die persoon wat as skriba verkies is, direk opeenvolgend weer gekies kan word, met ander woorde dat ' $n$ 'gedurige skriba' só moontlik gemaak is.

Of sulke gedagtes in hierdie artikels ingelees kan word, is moeilik te verdedig of te weerlê. Die praktyk ná Dordt dui daarop dat dit nie korrek is om sulke moontlikhede in die Dordtse Kerkorde te soek nie. Nie een van die twee skribas het, nadat die sinode verdaag het, bly funksioneer nie. Hulle was weer net 'gewone predikante' van hulle gemeentes.

Uit die voorgaande gegewens kan nou die volgende oor die skriba in die presbiteriaal-sinodale kerklike orde, soos dit in die vroeë Nederlandse Hervormde kerkordes neerslag gevind het, gestel word:

- Die skriba was 'n vaste funksie by elke vergadering van die ampte. 'n Praeses of voorsitter was nodig om die vergadering so te lei dat hy ordelik en gedissiplineerd toegespits sou bly op daardie handelinge waartoe hy die bevoegdhede gehad het. Net so nodig vir die vergadering was 'n skriba wat noukeurig en ywerig alles wat belangrik was moes opskryf, sodat die vergadering self kan weet en weer kan bekragtig dat wat hy besluit het sy gehoorsaamheid aan die Woord tot uitdrukking gebring het. Hierdie opgetekende besluite dien dan weer by opvolgende vergaderings om te sien of besluite uitgevoer is en te verhoed dat besluite gedupliseer sou word.

- Ten spyte daarvan dat dit 'n belangrike en verantwoordelike funksie gehad het, is die skribaat nooit beoordeel as 'n hoë posisie wat aan die ampsdraer wat daartoe geroep is 'n hoër eer en gesag verleen het as wat die ander ampsdraers op die vergadering gehad het nie. Trouens, waar die amp as sodanig nie as ' $n$ officium nie, maar as ' $n$ ministerium waardeer is, het die byeenkoms van die ampte-in-vergadering ten doel om te handel en te besluit hoe hulle hulle dienswerk, waarvan die opdrag en inhoud in die bevestigingsformulier omlyn is, ordelik gaan voer (Van Wyk 1989:103). In dié verband het die skriba wel die groot verantwoordelikheid om die handelinge en besluite ter wille van die goeie orde op te teken. Maar daarmee ontvang hy nie 'n hoër regeergesag as wat enige van die ander ampsdraers ter vergadering sou hê nie.

* Dit is ook duidelik dat die skriba van 'n regeervergadering slegs uit die lede van die betrokke vergadering gekies is. Dit het gegeld vanaf die kerkraadsvergadering tot by die sinode. Dit het eerstens ingehou dat die skriba dus 'n diensdoende ampsdraer moes wees. In die geval van die kerkraad was dit gewoonlik 'n ouderling en in die geval van 'n meerdere vergadering 'n diensdoende predikant. 
- Om op 'n meerdere vergadering sitting te kon neem, moes die betrokke ampsdraer afgevaardig gewees het deur 'n mindere vergadering, dit wil sê deur die kerkraad na die klassis of deur die klassis na die provinsiale sinode. Hieruit volg dat vir 'n predikant om op 'n meerdere vergadering sitting te kon hê, hy 'n 'gemeentepredikant' moes wees, dit wil se 'n predikant wat in 'n gemeente bevestig is en waar hy deel gevorm het van 'n kerkraad wat hom na 'n meerdere vergadering kan afvaardig. Dosente in die teologie wat wel steeds ampsvoorregte gehad het, is slegs adviserend op meerdere vergaderings toegelaat.

- Hieruit volg dat slegs 'n predikant wat 'n 'gewone gemeentepredikant' was, as skriba, en sekerlik ook as voorsitter, van ' $n$ meerdere vergadering gekies kon word.

- Ten opsigte van die funksie of taak wat aan die skriba opgedra is, was die bepaling duidelik: om ywerig en noukeurig op te skryf wat werklik ter sake en nodig en dus werd is om opgeteken te word. Hoegenaamd geen verdere administratiewe take en bevoegdhede is aan die skriba verleen nie. Enige verdere opdragte wat deur die vergadering aan hom gegee is, is nie aan hom gegee omdat hy skriba was nie, maar omdat ' $n$ meerdere vergadering enige van sy lede 'n opdrag kon gee om uit te voer.

- Na afloop van die vergadering en nadat die notule of acta bekragtig is, het die funksie van die skriba verval. Die skribaat van 'n besondere vergadering het dus net so lank as die vergadering se sitting geduur.

- Hoewel nie altyd so uitdruklik bepaal nie, het die rotasiebeginsel soos by die voorsitter ook ten opsigte van die skriba gegeld en is dieselfde predikant nie twee keer na mekaar as skriba van dieselfde vergadering gekies nie.

\section{DIE SKRIBA VAN DIE ALGEMENE KERKVERGADERING IN DIE NE- DERDUITSCH HERVORMDE KERK}

By die nagaan van die geskiedenis van die skriba van die Algemene Kerkvergadering in die NHKA vanaf die vestiging van die Kerk in Transvaal, is dit baie gou dujdelik dat daar ' $\mathrm{n}$ groot verskil bestaan in die funksie wat toegeken is aan die skriba in die presbiteriaal-sinodale kerkordes en die funksie wat die skriba in die Kerk gehad het en nog steeds het. Dit is vreemd dat dit so is, omdat die teendeel verwag kan word. Wat dit vreemd maak is die feit dat die beginseluitspraak wat gemaak word oor die Christologie en die ekklesiologie, soos vervat in die NHKA se belydenisskrifte, te wete die Nederlandse Geloofsbelydenis en die Heidelbergse Kategismus, 'n presbiteriaal-sinodale tradisie veronderstel. Deur steeds die belydenis te 
handhaaf en te bely, beteken mos dat die presbiteriaal-sinodale tradisie steeds lewend moet wees in die Kerk. So is dit inderdaad. Tog is dit ook waar dat daar steeds in die kerkordenende denke en praktyk van die Kerk vreemde elemente gevind word wat moeilik te rym is met die presbiteriaal-sinodale tradisie.

Om dié vreemde en merkwaardige teenstrydigheid te kan verstaan, is dit nodig om noukeurig rekening te hou met die dubbele lyn wat in die kerkordenende tradisie van die NHKA voorgekom het. Eerstens was daar die presbiteriaal-sinodale vorm van kerkregering soos dit in die Nederlandse Calvinistiese kerk ontwikkel het (Pont 1981:4). Tot by die begin van die negentiende eeu was dit die geldende tradisie van die kerk aan die Kaap. Selfs ook daarna het dit steeds 'n belangrike en uiteindelik bepalende rol gespeel in die kerkordelike ontwikkeling in die NHKA (Pont 1981:3-4). Die tweede minder bepalende lyn (Pont 1981:4) se beginpunt kan teruggevoer word tot by die invoering van die 'Algemeen Reglement voor het bestuur der Hervormde Kerk van het Koninkryk der Nederlanden' in 1816 (Haitjema 1951:4151). Van hierdie Algemeen Reglement sê Van Wyk (1989:134): 'Die reglement is die produk van die klemverskuiwing wat ingetree het toe die mondige mens met sy verstand onder die dekmantel van vryheid die normatiewe posisie van die Skrif oorgeneem het.'

Geen wonder dat dit uiteindelik verwoestend ingewerk het 'op die presbiteriaalsinodale kerkordelike tradisie met sy noue verbintenis aan die belydenisskrif en die Heilige Skrif nie (Pont 1981:4). Pont praat van hierdie tweede lyn enersyds as kollegialisme (Pont 1981:4) en andersyds as verenigingsreg (Pont 1982a:9), terwyl Van Wyk (1989:234) van verenigingsreg praat.

Met die invoering van hierdie Algemeen Reglement is 'n sekulariserende en demokratiserende tendens ingedra in die kerkordende denke in Nederland. Die kerk is gesien as 'n gewone vereniging en op basis van die verenigingsreg moes die kerklike struktuur gebou word. Hierdie denke was pragmatisties, en van die gedagte dat die kerklike orde 'n poging moet wees om die Christokrasie te verwesenlik, het niks oorgebly nie (Pont 1982a:9).

Deur die Kaapse Kerkwet van 1824, wat gebou was op die Algemeen Reglement van 1816, is hierdie gedagtes in die Kaapse kerk ingedra en het dit vanselfsprekend ook in die Kerkwet van 1862 van die NHKA ingang gevind. Hierdie Kerkwet is in 1869 hersien en het daarna met min ingrypende wysigings van krag gebly tot in 1951. In hierdie tydperk is dus ' $n$ ander tradisie as die presbiteriaal-sinodale in die kerklike denke van die NHKA ingedra en vasgelê. Die presbiteriaal-sinodale denke is gelukkig nie heeltemal verdring nie, maar tog sterk op die agtergrond gedruk. 
Vanuit die vertrekpunt dat die sigbare kerk niks meer as 'n vrywillige vereniging was nie, is die administratief-bestuurlike geweldig sterk beklemtoon. Dit het egter meegebring dat die belydende karakter van die presbiteriaal-sinodale kerkordes verdring is. Van hieruit weer het die regeervergaderings van die ampte niks anders as kerklike besture geword nie. So sterk was die beklemtoning van die gesag wat in die vergaderings gesetel het, dat die gesag van Jesus Christus as die enigste wat werklik gesag oor en in die kerk het, en die afgeleide gesag van die geroepe en bevestigde ampsdraers ernstig in gedrang gekom het. Pont (1982a:10) stel dat: 'In plaas van 'n dinamies-pneumatiese gesagsopvatting word hier 'n statutêr-juridiese gesag in die vergadering se hande gelê.'

Met hierdie gesagsverskuiwing is dit nie verbasend dat daar 'n hiërargie van vergaderings gebou is waarin die kerkraad die laagste en die Algemene Kerkvergadering die hoogste met die hoogste wetgewende, regsprekende en besturende gesag (Pont 1982a:10) geword het nie. Die hoogste gesag van die Algemene Kerkvergadering is nog verder onderstreep deur die tot stand bring van 'n Kommissie van die Algemene Kerkvergadering wat as kontinuerings- en uitvoerende kommissie tussen Algemene Kerkvergaderings die bopunt van "n piramidale gesagstruktuur van vergaderings' gevorm het (Pont 1982a:10).

Dit is byna vanselfsprekend dat in hierdie denke die sterk anti-hiërargiese en daarmee gepaardgaande en ondersteunende rotasiebeginsel van die presbiteriaalsinodale denke nie meer genoem is nie.

In hierdie struktuur het die skriba van die Algemene Kerkvergadering tot 1950 ook sy plek gehad. Dit is duidelik dat hy as funksionaris van die hoogste kerklike bestuur vanselfsprekend ' $n$ uitsonderingsposisie beklee het. Onder andere is dit bevestig waar die Algemene Kerkvergadering die 'hoogeerwaarde vergadering' en sy skriba die 'hoogeerwaarde skriba' genoem is.

Die funksie van die skriba het ook nie geëindig as die vergadering afgesluit is nie, omdat hy ook as skriba van die Algemene Kerkvergadering, skriba van die Kommissie van die Algemene Kerkvergadering moes wees tot by die volgende Algemene Kerkvergadering. Bowendien het die tendens vinnig posgevat om die funksionarisse van die Algemene Kerkvergadering vir lang tye aaneen te bly kies. Ten opsigte van die skriba kan die voorbeelde genoem word van ds $\mathrm{N} \mathrm{J}$ van Warmelo wat vir sestien jaar (1869-1885) en ds J van Belkum wat vir 25 jaar (1897-1922) ononderbroke skriba van die Algemene Kerkvergadering was (Pont 1955:97, 159; Pont, Botha \& Storm 1986:67). Die gebruik om elke keer 'n skriba te kies was wel daar, maar is tog nie benut om minstens van tyd tot tyd 'n ander predikant as skriba te kies nie. Dit moet wel toegegee word dat die voortdurende tekort aan predikante hierdie tradisie sterk aangehelp het. Tog is dit so dat veral ná 1900 daar mettertyd 
soveel meer predikante beskikbaar gekom het dat dit nie meer so 'n dwingende argument was nie.

So is die tradisie gevestig dat die skriba van die Algemene Kerkvergadering van die begin af nie alleen ' $n$ 'gedurige' skriba was nie, maar bowendien, as gevolg van die hiërargie van die vergaderings, ook ' $n$ uitsonderlike hoë funksionaris was. Ook die hiërargie het dus ingesluip.

Dit moet egter baie sterk beklemtoon word dat die afwyking weg van die presbiteriaal-sinodale kerkordenende denke af gelukkig nie beteken het dat leertug nie meer in die kerk toegepas kon word nie. In die eerste plek het die proponentsondertekeningsformule steeds die 'erkening van die belydenisskrifte as norm en reël van die prediking vereis' (Pont 1982a:11). Tweedens is die leertug nog altyd in die NHKA getrou gehandhaaf soos die leertugsake in die gevalle van ds $\mathrm{A} \mathrm{J}$ Begemann (1869), ds C J L Ruysch van Dugteren (1911) en prof A S Geyser (1961/1962) duidelik bewys.

Juis hierdie sterk vashou aan die leer en belydenis, was 'n belangrike bydraende faktor dat die vreemde kerklike struktuur nie die presbiteriaal-sinodale denke totaal uit die NHKA verdring het nie. Net soos in die Nederlandse Hervormde Kerk het ook in die NHKA 'n sterkerwordende onbehae met die vreemde stelsel gegroei. In Nederland is daar na langdurige worsteling in 1950 wel 'n nuwe kerkorde aanvaar wat meer in lyn was met die presbiteriaal-sinodale denke (Haitjema 1951:65-111; Van Wyk 1989:117-196).

Die noue bandê wat in daardie jare nog tussen die NHKA en die Nederlandse Hervormde Kerk bestaan het, het dit byna vanselfsprekend gemaak dat ook in die NHKA 'n nuwe kerkwet aanvaar moes word, geskoei op die lees van die Nederlandse Kerkorde. Ongelukkig het die nuwe Kerkwet wat in 1951 vir die NHKA aanvaar is, nie ook gepaard gegaan met 'n diepgaande worsteling soos in Nederland nie en ook nie 'voorafgegaan is en voortgevloei het uit ' $n$ indringende studie en bespreking van die kerk en sy struktuur nie' (Pont 1982a:11). Die gevolg hiervan was dat, hoewel die Kerkwet van 1951 die tweede kerkordenende lyn waarna reeds verwys is, deurbreek het en die Kerkwet inderdaad "n presbiteriaal-sinodale sisteem struktureer' (Van Wyk 1989:353), daar tog steeds leemtes (Pont 1982a:11) en oneffenhede (Van Wyk 1989:353) voorkom. Beide Pont en Van Wyk wys 'n aantal leemtes en oneffenhede in die genoemde werke uit.

Wat vir die saak rondom die skriba van belang is en terselfdertyd illustreer hoedat presbiteriaal-sinodale beginsels enersyds hulle plek in die Kerkwet gevind het, maar terselfdertyd deur die voortsetting van besoedelde tradisies andersyds tog kragteloos gemaak is, is die volgende kommentaar van prof Pont oor enkele aspekte van die Kerkwet van 1951: 
Die amp word meer as ' $n$ dienswerk waardeer en die beroemde antihiërargiese klousule van die Emdense sinode van 1571 word in art V1 heringevoer. Maar jammer genoeg, is die hiërargie van vergaderings en die funksionering van die gesag in en van die kerk nie ook verander nie. Hier het die statutêr-juridiese opvatting, waarskynlik vanweë administratiewe pragmatisme, tog weer oor die Christokraties-pneumatiese oorwegings geseëvier. Nie alleen is die kontinueringsvergaderings van die meerdere vergaderings gehandhaaf nie, maar mettergaan is dit ook uitgebrei en het die bestuursopvatting ten opsigte van die vergaderings van die ampte steeds sterker geword. Daarmee word in feite en deur die afwesigheid van die rotasiebeginsel by die benoeming van afgevaardigdes na die meerdere vergaderings, die anti-hiërargiese klousule van Art Ses kragteloos gemaak.

(Pont 1982a:12)

Juis hierdie bepaalde leemtes wat hier aangedui word, het tot gevolg gehad dat die 'vreemde' tradisie ten opsigte van die skriba van die Algemene Kerkvergadering gehandhaaf is en nie die presbiteriaal-sinodale siening van die skriba nie. Die skriba was steeds ' $n$ 'gedurige' skriba - van die hoogste vergadering en van die kontinueringskommissie van die hoogste vergadering. So het ds T F J Dreyer sr, wat reeds vanaf 1934 skriba was, skriba gebly tot in 1964 toe hy gevra het om nie weer verkiesbaar te wees nie. Sy opvolger, ds P M Smith, het vanaf 1964 tot 1983 gedien, toe ook hy gevra het om nie weer verkiesbaar te wees nie.

Die feit dat hierdie twee ampsdraers vir lang tydperke aaneen gedien het en bowendien beide voortreflike werk gelewer het, het feitlik vanselfsprekend meegebring dat al meer en meer werk deur hulle as 't ware aangetrek is. In die geval van ds Smith het 'n verdere aspek bygekom wat die NHKA nog meer bederf het: Hy het naamlik as kompilator van kerklike publikasies en beriggewing, 'n voltydse sinodale pos beklee wat hom heeldag op kantoor gehou het en dan was dit dieselfde kantoor vanwaar hy sy verpligtinge as skriba, wat toe reeds baie wyer gestrek het as die skryf van die notules van die vergaderings, uitgevoer het. Trouens, dit was ook toe reeds so dat die hou van die notule nie meer die primêre taak van die skriba was nie, maar wel van die vise-skriba en die administrateur van die kerklike administrasie. Hoewel dit inderdaad so is dat die pos van die kompilator in teorie nie verband gehou het met die skribaat nie, het die verbinding van die twee funksies in een persoon tog in praktyk daartoe gelei dat ds Smith deur lidmate en ook ampsdraers van die Kerk as voltydse skriba beskou is.

Ter wille van 'n volledige perspektief, is dit belangrik om te onthou dat die instelling van die pos van kompilator nie sonder teenstand geskied het nie. Die saak 
is selfs op twee predikantevergaderings bespreek, waar argumente, dat op die wyse 'n voltydse skriba ingevoer wou word, ook gehoor is (NHKA 1970:596). In sy verslag aan die Algemene Kerkvergadering van 1970 het ds Smith nogeens na hierdie bedenkinge verwys toe hy weer bevestig het: 'Die pos van skriba van die Algemene Kerkvergadering is nie ' $n$ voltydse pos nie en dit word ook nie beplan om dit voltyds te maak nie.'

Ds Smith het self reeds in 1975 daarop gesinspeel dat die skribaat 'n voltydse pos behoort te wees. In sy verslag van Februarie 1975 aan die Kommissie van die Algemene Kerkvergadering het hy oor die skribaat gesê: 'Dit bly steeds ' $n$ toevoeging tot die taak van die kompilator vir kerklike publikasies en beriggewing. Dit is 'n oop vraag of dit nog as 'n deeltydse taak uitgevoer sal kan word veral as die Algemene Kerkvergadering in aanmerking geneem word.'

Dit is geen wonder nie dat toe ds J C de Lange in 1983 by ds Smith as skriba van die Algemene Kerkvergadering oorgeneem het, hy gekonfronteer is deur ' $n$ werklading wat deur die jarelange tradisie aan die skriba toegeken is, wat nie deur 'n predikant wat voltyds in 'n standplaas staan, as bykomende taak behartig sou kon word nie.

\section{DIE BESLUIT VAN DIE ALGEMENE KERKVERGADERING VAN 1986}

In Mart 1984 hel die Kommissie van die Algemene Kerkvergadering aan die Moderamen opdrag gegee om ondersoek te doen na 'n tweede evangelisasiepredikant vir Pretoria, juis om ds De Lange, wat toe evangeliesasiepredikant was, tegemoet te kom. Aan hierdie opdrag het die Kommissie 'n verdere opdrag verbind, naamlik dat die moontlikheid van 'n voltydse skriba terselfdertyd ondersoek moes word.

By dié ondersoek het die Moderamen ook nog voor hom twee versoeke gehad. Die eerste was van die Raad vir Evangelisasie, ondersteun deur die Werkgroep Apostolaat, dat 'n voltydse sekretaris vir die Kommissie van die Algemene Kerkvergadering benoem sou word. Met 'n voltydse sekretaris het die Raad klaarblyklik net 'n (administratiewe?) hulp vir die skriba beoog. Die tweede was van die Werkgroep Prediking en Erediens wat sou wou sien dat 'n skakelbeampte aangestel sal word om namens die NHKA met die media te skakel (NHKA 1986a:38).

Die Moderamen se oordeel was dat hierdie twee poste goedskiks saamgevoeg kon word in die persoon van 'n voltydse skriba. By die Raad vir Regsadvies is navraag gedoen of die betrokke Bepalings so gewysig sou kon word om hiervoor voorsiening te maak. Die Raad het enersyds die beginseladvies gegee wat reeds in die Inleiding genoem is, naamlik dat met ' $n$ voltydse skriba die beginsel van hiërargie 
ingevoer sou word. Andersyds het die Raad die volgende praktiese advies gegee (NHKA 1986a:38): 'Dat daar eerder 'n "skribaat" saamgestel sal word wat sal bestaan uit die gekose skriba en vise-skriba en 'n derde lid in 'n permanente pos vir skakeling met die media en talle ander funksies wat slegs deur ' $n$ voltydse persoon doelmatig behartig kan word.'

Die Kommissie van die Algemene Kerkvergadering het die advies van die hand gewys en besluit om die Algemene Kerkvergadering wel te versoek om 'n voltydse skriba goed te keur en in te stel. Die Kommissie het die volgende motivering voorgelè (NHKA 1986b:38-39):

Dit blyk dat dit nie meer moontlik is om 'n voltydse standplaas te beman en tegelyk skriba te wees nie.

'n Derde persoon, soos aan die hand gedoen deur die Raad vir Regsadvies, sal die probleem nie ondervang nie. Feit is dat kommunikasie by voorkeur met die skriba self (sal) geskied. Verder is dit wesenlik dat, volgens die gees en bedoeling van Bepaling 14.1(a), dit ook in die toekoms so sal wees dat die getuienis van die kerk hoofsaaklik deur die voorsitter en skriba van die Kommissie van die Algemene Kerkvergadering verwoord sal word. 'n Derde persoon sal dus wel sekere administratiewe pligte kan uitvoer, maar sal nie die werklas van die skriba voldoende verminder om hom in staat te stel om naas die skribaat 'n voltydse standplaas te bly beman nie.

Dit lyk die beste weg te wees om die samestelling van die kommissie so te wysig dat die skriba nie meer telkens op 'n Algemene Kerkvergadering verkies sal word nie, maar vir 'n langer tydperk verkies of benoem sal word op 'n wyse wat sover moontlik sal verseker dat hy die vertroue van die kerk geniet.

Dit lyk ook prakties dat bepaalde funksies wat tans aan die administrateur opgedra is, deur 'n voltydse skriba behartig sal word, byvoorbeeld die toesig en beheer oor kerklike publikasies, Kital en die Argief.

Oor hierdie motivering van die Kommissie is 'n paar opmerkings nodig:

- Hoewel beswaar teen die voorlegging van die Raad vir Regsadvies moontlik is omdat die gegewe advies nie uitvoeriger omskryf en behoorlik gemotiveer was nie, is dit tog teleurstellend dat die Kommissie hoegenaamd nie geantwoord het op die beginselbeswaar van hiërargie nie. In die presbiteriaal-sinodale sisteem is die anti-hiërargiese beginsel baie belangrik geag en 'n moontlike skending 
daarvan het seker ernstige en diepgaande besinning nodig gemaak. Tog is al motivering wat gegee word die praktiese situasie.

* Dit is baie duidelik dat kommunikasie en dan veral kommunikasie na buite die NHKA, as ' $n$ baie belangrike funksie van die skriba beskou is. Dit hou in dat die skriba gesien word as iemand soos 'n openbare skakelbeampte van die Kerk. Dit is nogal begryplik dat in die huidige tydsgewrig geoordeel word dat 'n kerk ook so 'n funksionaris benodig. Want nie alleen word die voordele van so 'n funksionaris vanuit die sekulêre wêreld die kerk voor oë gehou nie, maar ook funksioneer die aartsbiskop in kerke met 'n hiërargiese regeringsisteem in praktyk op dié wyse. Dit laat die gevoel by kerke waar die ampte-in-vergadering regeer ontstaan dat hulle minder invloed in die openbare lewe sal hê omdat reaksie op bepaalde aangeleenthede soveel langer neem.

- Daar word verwys na Bepaling 14.1(a) wat soos volg lui: 'Die Kommissie van die Algemene Kerkvergadering praat, getuig en tree namens die Kerk op wanneer die Algemene Kerkvergadering nie sit nie.' Hierdie Bepaling word in die motivering deur die Kommissie so verstaan dat dit 'wesenlik' is dat dit hoofsaaklik die taak van die voorsitter en skriba sal wees om die Kerk se getuienis te verwoord. Daarmee word die taak wat in die Bepaling aan die Kommissie opgedra is, waar dit gaan om die ampte-in-vergadering wat regeer, nou die verantwoordelikheid van die voorsitter en die skriba. Prof Pont wys daarop dat deur hierdie Bepaling selfs die Algemene Kerkvergadering nie die bevoegdheid het om namens die Kerk op te tree nie (Pont 1982b:126). In die motivering word dit nou as 'n 'wesenlike' taak vir die voorsitter en skriba opgeëis. Daarvoor moet die skriba 'n voltydse aanstelling word. Die gevaar van 'n 'gesaghebbende gesamentlike episkopaat', waarna Pont (1982b:130) verwys, is hier werklik wesenlik teenwoordig.

- Dit wil voorkom of die taak van die voltydse skriba nie soveel administratiewe verpligtinge sou insluit, dat 'n voltydse administratiewe hulp sy werk wesenlik sal verminder nie. Dit impliseer dat ander opdragte as administratiewe opdragte, soveel was dat dit 'n voltydse pos regverdig het.

Merkwaardig genoeg word daar dan steeds verdere werk aan hom opgedra as gestel word dat hy bepaalde funksies wat aan die administrateur opgedra is soos byvoorbeeld die toesig en beheer oor kerklike publikasies, KITAL en die Argief kan oorneem. Die vraag is: As die skribaat op sigself 'n voltydse pos is, waarom nog meerdere verantwoordelikhede byvoeg?

Die Algemene Kerkvergadering wat vanaf 12-19 Mei 1986 vergader het, het sonder noemenswaardige bespreking en teenstand aan die versoek van die Kommissie vol- 
doen. Dat die tydperk van ses jaar na drie jaar verminder is, was geen wesenlike verandering nie, maar het die besluit in 'n sekere sin nog meer problematies gemaak. Oor hierdie besluit is die volgende opmerkings nodig:

* Dit is merkwaardig dat die instelling van die kompilator vir kerklike publikasies en beriggewing vroeër teengestaan is met die argument dat dit nie 'n 'verbloemde' voltydse skriba mag wees nie, terwyl in 1986 daar feitlik geen teenstand was by die instelling van 'n voltydse skriba nie.

* Hoe 'n voltydse pos met 'n sesjaarlikse of driejaarlikse verkiesing te rym is, is nie duidelik nie. Wat hier gebeur, is dat die dienaar van die Woord wat verkies word wel nie van sy ampsvoorregte ontneem word nie, maar dat tog van hom verwag word om sy bepaalde standplaas waaraan hy verbind is te verruil vir die standplaas van skriba. Hy word dus in werklikheid tot skriba beroep, maar dan telkens net vir'n tydperk van drie jaar. Indien dieselfde dienaar van die Woord weer en weer verkies word, beteken dit in werklikheid dat hy telkens weer beroep word na die standplaas wat hy steeds vul. Indien 'n ander dienaar van die Woord as skriba gekies sou word, het dit die implikasie dat die sittende skriba summier uit sy standplaas ontslaan is. Trouens, in wese het dit die implikasie dat die Algemene Kerkvergadering op hierdie wyse, sonder klagskrif en sonder verhoor, die uitspraak maak dat die betrokke ampsdraer nie sy werk behoorlik gedoen het nie en daarom vervang moet word. Dit bring die vraag na vore of die enigste kerkregtelik korrekte manier om 'n voltydse skriba te vervang, dan nie sal wees om deur klag, verhoor en tugstappe hom uit sy standplaas te verwyder nie.

* Benewens die feit dat hierdie soort optrede rondom die amp van die dienaar van die Woord ongehoord is in die presbiteriaal-sinodale sisteem, is dit ook uiters onbillik teenoor die persoon wat as skriba gekies word om dan na drie jaar summier ontslaan te word. Hy verloor dan onmiddellik sy lewenstog omdat die nuutgekose skriba dadelik in die standplaas deur die verkiesing benoem is en daarom versorg moet word. Die argument dat die ontslaande skriba dan maar weer ' $n$ ander beroep kan aanneem los die probleem nie op nie. Want in die huidige situasie van 'n oorskot aan predikante mag die wag op 'n beroep selfs jare duur.

- Dit is tog ook 'n vraag wat die Kommissie en die Algemene Kerkvergadering se diepste motiewe was vir die verbinding van 'n voltydse pos aan 'n periodieke, sesjaarlikse of driejaarlikse verkiesing. Was dit net om die beswaar van hiërargie so te probeer besweer, of was dit dalk omdat besef is dat 'n voltydse skriba nie vanuit die presbiteriaal-sinodale sisteem verdedigbaar is nie en nou 'n 
soort kompromie geskep is? In wese sluit 'n voltydse pos en gereelde verkiesing mekaar tog uit. Dit bring mee dat die argument gebruik kan word dat die gereelde verkiesing in werklikheid net oëverblindery is.

- Dit is byna voor die hand liggend dat hierdie besluit in die NHKA in praktyk sal beteken dat ' $n$ skriba wat eenmaal gekies is, net op eie versoek of by aanvaarding van emeritaat, vervang sal word. Die lank gevestigde tradisie van 'n 'gedurige' skriba maak dit meer as 'n waarskynlikheid. Hoe sterk hierdie tradisie in die NHKA leef, blyk by die inskrywing van die rotasiebeginsel in die Bepalings van die Kerkwet ten opsigte van die ringsvergadering.

Toe die Bepalings in die Kerkwet rondom die ringsvergadering in die afgelope dekade gewysig is en die rotasiebeginsel ingeskryf is, is daar 'n verdere agterdeur oopgelaat om die rotasiebeginsel te ontkom. So word in Bepaling 7.2(b) gestel: "n Ouderling of 'n diaken sal verkieslik nie na meer as drie agtereenvolgende vergaderings afgevaardig word nie', en in Bepaling 9.6, 'Vervolgens kies die vergadering uit die aanwesige predikante 'n voorsitter en skriba met dien verstande dat 'n predikant verkieslik nie meer as drie jaar na mekaar as voorsitter of skriba gekies sal word nie.'

Dit was die eerste keer dat die rotasiebeginsel in die Kerkwet ingeskryf is, al was dit ook nie die streng rotasiebeginsel wat in die vroeë presbiteriaal-sinodale kerkordes gegeld het dat funksionarisse net vir een vergadering gekies is nie. Nogtans is deur die invoeging van die woord 'verkieslik' weer die moontlikheid oopgelaat dat 'n vergadering tog kan besluit om anders te handel. Die argument dat bepaalde praktiese omstandighede die rotasiebeginsel kan bemoeilik, kan wel aangevoer word. Tog sou dit beter wees om as algemene reël die beginsel van rotasie neer te lê en dan voorsiening te maak vir die uitsonderings as gevolg van omstandighede.

Terselfdertyd is dit steeds ' $n$ vraag of ringe in praktyk werklik deurgaans probeer om by die rotasiebeginsel te hou. Die indruk bestaan dat dit baie dikwels gebeur dat dieselfde afgevaardigdes steeds jaar na jaar na die Ringsvergadering gestuur word en dieselfde funksionarisse jaar na jaar gekies word, sonder dat oor die rotasiebeginsel gedink word.

Bowendien sal by die verkiesing van die skriba elkeen wat moet stem gekonfronteer sit met die moontlike probleme wat vir die uitgestemde skriba kan voorlê en dan maar uit meelewing tog nie teen hom stem nie. Van 'n werklike verkiesing is daar dan nie meer sprake nie.

- 'n Verdere probleem wat die voltydse skriba meebring is dat hy in 'n sinodale standplaas geplaas word sonder binding aan 'n plaaslike gemeente waar hy deel kan hê aan die primêre regeervergadering van die amp, naamlik die kerkraad, 
en vanwaar hy dan, in ooreenstemming met die presbiteriaal-sinodale sisteem, na ' $n$ meerdere vergadering afgevaardig kan word. Dit is natuurlik so dat in die NHKA alle dienaars van die Woord sitting het op die Algemene Kerkvergadering omdat die vergadering slegs ten opsigte van die ander ampte afvaardiging vereis (NHKA 1989:Bepalings 10.2, 12.6:18, 19). Omdat hy wesenlik predikant in buitengewone diens is in ' $n$ sinodale standplaas, het die skriba wel sitting op die Algemene Kerkvergadering. Maar juis deur hom predikant in besondere diens te maak kom die problematiek van die predikant in besondere diens in die algemeen se volle sittingsreg op ' $n$ meerdere vergadering terwyl hy geen sittingsreg op 'n mindere vergadering het nie, sterk op die voorgrond. So word 'n ander afwyking van die presbiteriaal-sinodale sisteem in die kerklike orde van die NHKA sterk belig.

Op sy vergadering van 28 November 1986 het die Kommissie van die Algemene Kerkvergadering die opdrag oor die omskrywing van die werkterrein en verantwoordelikheid van die skriba wat na hom verwys is, uitgevoer. 'n Baic belangrike uitspraak van die Kommissie wat nader beskou moet word, was: 'Die Skriba is die uitvoerende en koördinerende ampsdraer van die Algemene Kerkvergadering' (NHKA 1986b:33).

In die NHKA was 'n ampsdraer nog altyd iemand wat ná roeping, verkiesing en bevestiging toegelaat is tot die amp. Sy ampsvoorregte en ampsverpligtinge is sorgvuldig in die betrokke bevestigingsformulier omskryf. As draer van die amp was hy dienaar wat in opdrag van sy Heer die gemeente bedien het. Van 'n vergadering kan hy nie ampsdraer wees nie, want die vergadering het nie aan hom die amp toegeken nie. Die woord 'funksionaris' sou dalk beter as ampsdraer gepas het. Dit wil al voorkom of die gebruik van die woord 'ampsdraer' 'n verleentheid moes omseil. Die administrateur is immers reeds hoofamptenaar van die Algemene Kerkvergadering (Bepaling 190 van die Kerkwet). Verder is uitvoerende en koördinerende take of funksies aan die skriba toegeken - iets wat ook aan die administrateur toegeken word. Die vraag is wat dan oorbly van die dienswerk van die predikant waarvan die begin en die einde die prediking, die verkondiging, die uitleg en die toepassing van die Woord van God is (Pont 1978:56). Waar die amp in die presbiteriaal-sinodale sisteem funksioneel is, is die volgende vraag dan of iemand wat nie meer die primêre funksies van die amp uitvoer nie, nog langer predikant kan wees.

Dit is seker nou genoegsaam duidelik dat 'n voltydse skriba van die Algemene Kerkvergadering nie in lyn lê met die beginsels van die presbiteriaal-sinodale kerklike orde nie. Bowendien het hierdie studie ook aan die lig gebring dat daar steeds ook 
ander kerkordelike reëlings in die NHKA bestaan wat in die lig van die presbiteriaal-sinodale sisteem problematies is en verdere ernstige nadenke van die Kerk verg.

Uiteindelik dring die vraag na vore waarom die Algemene Kerkvergadering in 1986 so maklik 'n besluit kon neem oor ' $n$ voltydse skriba, sonder om die waarskuwende advies ter harte te neem dat 'n beginsel van die presbiteriaal-sinodale kerkordelike sisteem so in gedrang gebring kon word. Meer as een antwoord is moontlik. Die antwoorde is egter pynlik, omdat dit ook ernstige beskuldigings bevat.

'n Eerste en milde antwoord kan gegee word in die woorde van Van Wyk (1989:354) dat die nadelige invloed van die denke van die verenigingsreg binne die Kerk steeds latent is en makliker begryp word as die reformatories-kerkregtelike denke.

Prof Pont stel dieselfde saak bietjie skerper as hy sê dat die NHKA dit blykbaar nog nie finaal uitgemaak het of hy die Calvinisties presbiteriaal-sinodale struktuur of die rasionele verligtingsteologie se sinodale struktuur verkies nie (Pont 1982b: $105)$.

'n Verdere, baie skerp antwoord kom ook van prof Pont as hy sê 'dat die kennis van die oorspronklike Calvinistiese ekklesiologie en kerkreg in ons kerklike kringe maar vaag is...' (Pont 1982b:104). Om 'n Calvinistiese kerk te beskuldig dat hy 'n gebrek aan kennis het van die Calvinistiese denke, is sekerlik pynlik.

\section{'N MOONTLIKE OPLOSSING}

Om te verhoed dat hier bloot ad hoc en pragmatiese oplossings aangebied word, is dit nodig om eers weer duidelik te sê van watter grondliggende uitgangspunt af vertrek word. Dit lyk vanselfsprekend dat in 'n Calvinistiese hervormde kerk die kerkordelike reëlings die uitdruklike bedoeling sal hè om vanuit die Skrif soos verstaan deur die belydenisskrifte, die lewe van die kerk, as liggaam van Jesus Christus, verantwoordelik te orden. Die uitgangspunt is dan dat die Christologie en ekklesiologie wat in die NHKA se belydenisskrifte bely word, alleen behoorlik praktiese gestalte gegee kan word in 'n presbiteriaal-sinodale kerkordelike struktuur. Met Pont word volkome ingestem as hy sê dat dit steeds 'die beste kerkordelike struktuur [is] om die gehoorsaamheid aan Jesus Christus, die Hoof van die kerk, tot uitdrukking te bring' (Pont 1982b:132). Hierdie stelsel is juis ontwerp om die dinamies pneumaties-Christokratiese ekklesiologie van die belydenisskrifte ook prakties gestalte te gee.

In die lig van die gevare wat hierdie struktuur steeds bedreig, soos onder andere dat daar maklik 'n aksentverskuiwing na 'n statutêr-juridiese interpretasie en verstaan van die kerklike struktuur kan kom (Pont 1982a:7), is 'n voorwaarde op pad na 
'n oplossing 'n oproep tot die Kerk dat hy nog skerper presbiteriaal-sinodaal sal dink. Na aanleiding van Noordmans se werk 'Kerkelijk denken voorwaarde voor kerkorde' (1984) word die stelling gemaak: Presbiteriaal-sinodale denke is die voorwaarde vir 'n presbiteriaal-sinodale kerkorde.

Die probleem waarmee geworstel word, is die feit dat die werklading wat tans op die skriba rus, so toegeneem het dat dit nie meer 'deeltyds' hanteer kan word nie. 'n Belangrike vraag wat eers weer gevra moet word, is wat die taak sou wees van 'n skriba in die presbiteriaal-sinodale sisteem. Die antwoord is ook reeds gegee, naamlik die optekening van die handelinge en besluit van die vergadering waarvan hy lid is. Ander opdragte is nie aan hom gegee omdat hy skriba was nie, maar omdat hy ' $n$ lid van die vergadering was en aan enige lid 'n opdrag gegee kon word om 'n bepaalde besluit uit te voer of toe te sien dat dit uitgevoer word. Sy primêre en enigste taak as skriba was om ywerig en noukeurig op te teken wat opgeteken moes word.

'n Verdere vraag wat hierna aan die orde kom, is hoe dit presbiteriaal-synodaal gesproke kon gebeur dat die skriba se verantwoordelikhede dan so kon toeneem dat hy voltyds moet wees? Hoewel meer as een antwoord gegee sal kan word, is daar net een antwoord wat werklik kerkordelik in 'n presbiteriaal-sinodaal gestruktureerde kerk as korrek aanvaar sou kon word en dit is dat die betrokke vergadering so aanhoudend, sonder onderbreking sit dat die skriba niks anders meer kan doen as net optekenwerk nie. Maar dan geld dit natuurlik ook van al die lede van die betrokke vergadering. Almal sal in so 'n geval 'voltyds' moet wees. Alle ander antwoorde, wat hulle inhoud ookal sou wees, sou net een ding kan beteken en dit is dat afgewyk is van die presbiteriaal-sinodale siening van die funksie van die skriba.

Hieruit volg dat die skriba van die Algemene Kerkvergadering van die Kerk in werklikheid nie meer skriba is in die presbiteriaal-sinodale sin van die woord nie. Soos geblyk het, is sy primêre taak selfs nie eers meer om die notule van die Algemene Kerkvergadering te hou nie. Onder die naam van skriba het hy in werklikheid 'n ander funksionaris geword.

Die eerste stap na 'n oplossing sou dan wees om die funksies van die skriba in die Kerk weer terug te snoei tot by of minstens tot so na as moontlik aan die funksie wat aan die skriba in 'n presbiteriaal-sinodale sisteem toegeken is. Dit beteken dat sy primêre verantwoordelikheid sal wees die opteken van die handelinge en besluite van die Algemene Kerkvergadering, wat tans driejaarliks sit, die Kommissie van die Algemene Kerkvergadering, wat vier keer per jaar vergader en die Moderamen wat ongeveer twaalf keer per jaar vergader.

Dit word toegegee dat hierdie eerste stap van terugsnoeiing pynlik mag wees, omdat dit radikaal ingryp op die tradisie wat al jare lank rondom die skriba gevestig 
geraak het. Aan die ander kant sal dit dalk net 'n drastiese ingreep kan wees wat sal verhoed dat stelselmatig, hoewel dalk onbewus, al verder van die presbiteriaal-sinodale sisteem af weg beweeg word.

Die tweede stap wat gelyktydig met en ondersteunend tot die eerste stap geneem moet word, is om 'n noukeurige evaluering te mak van al die ander take wat tans bykomend van die skriba verwag word, om te kan bepaal watter alleen deur 'n lid van die regeervergadering hanteer kan of behoort te word en watter goedskiks deur 'n amptenaar behartig kan word. Dié wat net deur ' $n$ lid van die regeervergadering self gedoen moet of behoort te word, word dan deur die vergadering aan een van sy lede opgedra. Dit kan ook die skriba wees. Nie alles hoef en kan egter aan die skriba opgedra word nie. Al die ander verantwoordelikhede word na 'n aangestelde administratiewe amptenaar verwys.

'n Beswaar kan wees dat die skriba steeds geweldig baie vergaderings moet hanteer, naamlik in 'n tydperk van drie jaar ongeveer sewe dae van die Algemene Kerkvergadering, twaalf dagvergaderings van die Kommissie van die Algemene Kerkvergadering en 36 halfdagvergaderings van die Moderamen. Dit geld natuurlik van al die lede van die Moderamen wat presies dieselfde aantal sittings moet bywoon. By die optekeningswerk kan die skriba gehelp word deur 'n tweede of 'n vise-skriba, soos wat tans reeds bestaan. Bowendien kan die twee addisionele predikantslede op die Algemene Kommissie ook gebruik word.

Om te verhoed dat die druk te lank en aanhoudend op 'n enkele predikant gelê word, is dit voor die hand liggend om die rotasiebeginsel ook ten opsigte van die $\mathrm{Al}$ gemene Kerkvergadering, sonder die moontlikheid van 'n agterdeur, tce te pas. Dit sou 'n baie belangrike stap nader aan die hart van die presbiteriaal-sinodale stelsel wees, omdat die rotasie-beginsal, wat as ondersteuning en bevestiging van die antihiërargiese beginsel, so kenmerkend is van hierdie kerklike orde. Daar kan tog nie beginselbesware bestaan teen die invoering van die rotasiebeginsel ook ten opsigte van die Algemene Kerkvergadering nie, as dit reeds by die ringsvergadering bestaan. 'n Tydperk van een, of hoogstens twee termyne kan as tydperk vir rotasie geld.

Die druk sou nog verder verminder kon word as die Algemene Kerkvergadering jaarliks sou vergader en die Kommissie van die Algemene Kerkvergadering en die Moderamen se vergaderings gehalveer word, en die rotasietermyn dan na hoogstens twee jaar verminder word. Die probleem is natuurlik dat ' $n$ Algemene Kerkvergadering met die huidige ledetal van ongeveer 700 moeilik jaarliks sal kan vergader. Dit hoef nie 'n struikelblok te wees nie, want 'n kleiner Algemene Vergadering wat trapsgewys saamgestel is, is nader aan die tradisionele presbiteriaal-sinodale sinnde as die tans bestaande kerkraadsinode in die NHKA (Pont 1982b:119; vgl ook Pont 
1970:118-145). Ter ondersteuning kan daarna verwys word dat die Inligtingsvergadering, bestaande uit die ringskommissies en Kommissie van die Algemene Kerkvergadering, tans reeds met gemak jaarliks vergader. In so 'n geval sal natuurlik ook die beginsel van afvaardiging van predikante, soos by die ringsvergadering, toegepas moet word. Dit sal die noodwendige gevolg hê dat slegs predikante wat in gemeente-standplase staan en op die plaaslike kerkraad sit, as skriba sal kan dien. Daarmee sal aan nog ' $n$ tradisie van die presbiteriaal-sinodale orde voldoen word.

Die gedagte van 'n administratiewe beampte wat die totale administrasie van al die vergaderings moet hanteer, moet nog verder aangeraak word. Die vraag is of dit nie juis die primêre taak en verantwoordelikheid van die administrateur van die kerklike administrasie moet wees nie. Of om dit bietjie anders te stel: Die administratiewe amptenaar wat aangestel word om die administrasie rondom die Algemene Kerkvergadering, die Kommissie van die Algemene Kerkvergadering en van die Moderamen te behartig, is die hoofbeampte van die totale kerklike administrasie. In die eerste deel van Bepaling 190 van die Kerkwet staan dit trouens reeds: 'Die administrateur is die uitvoerende en koördinerende hoofbeampte van die Algemene Kerkvergadering.'

Die feit dat by die aanstelling van 'n voltydse skriba dadelik opdrag gegee is dat die verhouding tussen die skriba en die administrateur ook noukeurig omskryf moet word, is baie duidelik ' $n$ aanduiding dat die voltydse skriba besig was om in te beweeg op die terrein van die administrateur. In plaas van om 'n voltydse skriba aan te wys wat van die take van die administrateur oorneem om sy voltydse pos te regverdig, kon eerder van die administratiewe verantwoordelikhede wat mettertyd op die skriba gelaai is, na die administrateur, waar dit eerder tuishoort, oorgeskuif gewees het. Dit sou buitendien geen kerkordelike probleme skep om in die administrateur se personeel addisionele hulp aan te stel nie. Ook hier moet toegegee word dat dit ernstige herbesinning oor die tak en die siening van die administrateur sal meebring en dalk ook pynlike snoeiwerk.

Die vraag of die administratiewe amptenaar (= administrateur) 'n predikant moet wees, is in diepte met ds De Lange, die eerste voltydse skriba wat in April 1991 emeritaat aanvaar het, bespreek. Vanuit sy praktiese ervaring oor die afgelope vyf jaar is dit sy mening dat dit inderdaad bepaalde voordele kan inhou as die persoon 'n predikant kan wees met minstens tien jaar ervaring en wat ook duidelik blyke daarvan gegee het dat hy oor 'n goeie organisasievermoë beskik. Hy stel dit egter nie as ' $n$ absolute voorwaarde nie en ook ' $n$ nie-predikant met die nodige kwaliteite sou die pos kon vul. Bowendien meen hy ook dat 'n predikant wat aangestel sou word, nie sy ampsvoorregte hoef te behou nie, omdat hy nie meer funksioneel die amp beoefen nie. 
Behalwe hierdie aspek, is ook die hele aangeleentheid van die voltydse skriba met ds De Lange bespreek. Dit het geblyk dat hy al die beginsels van die presbiteriaal-sinodale sisteem volledig aanvaar. Hy is ten gunste van die invoering van die rotasiebeginsel vir alle meerdere vergaderings en dit is ook sy oorwoë mening dat die skriba vir hoogstens twee termyne sou dien. Trouens, in breë trekke het hy met die oplossings wat hier aan die hand gedoen is, saamgestem.

'n Laaste vraag is of hierdie oplossings byderwets en effektief sal wees en nie dalk oudmodies en irrelevant nie. As hierdie oplossings in lyn lê met die ekklesiologie van die belydenisskrifte en kan dien om die Kerk 'n dinamies pneumaties-Christokratiese organisme te laat wees, is so 'n vraag in werklikheid nie ter sake nie. Nogtans sou 'n skriba, wat nie deur administratiewe sake geknel word nie, net so maklik en net so effektief vir skakeling na buite kan sorg as wat 'n voltydse persoon dit sou kon doen. Bowendien kan die vise-skriba of enige lid van die Algemene Kerkvergadering of die Kommissie van die Algemene Kerkvergadering 'n bepaalde opdrag ontvang om uit te voer en dan terug te rapporteer. Dit kan net so byderwets en effektief wees as wat 'n voltydse skriba dit sou kon doen.

\section{Literatuurverwysings}

Bouwman, H 1934. Gereformeerd Kerkrecht. 2e deel. Kampen: Kok.

Donner, J H \& Van den Hoorn, S A sj. Acta of handelingen der nationale synode 1618-1619. Utrecht: Den Hertog.

Haitjema, Th L 1951. NedeHands Henormd Kerkrecht. Nijkerk: Callenbach.

Nederduitsch Hervormde Kerk van Afrika 1970. Agenda van die Algemene Kerkvergadering. Pretoria: NHKA.

--- 1975. Notule van die Kommissie van die Algemene Kerkvergadering JanuarieMaart 1975. Pretoria: NHKA.

-- 1986a. Notule van die Algemene Kerkvergadering. Pretoria: NHKA.

-.- 1986b. Notule van die Kommissie van die Algemene Kerkvergadering November 1986. Pretoria: NHKA.

-.. 1989. Kerkwet en Bepalings van die Nederduitsch Hervormde Kerk. Pretoria: NHKA.

Noordmans, O 1984. Kerkelijk denken voorwaarde voor kerkorde. Verzamelde werk V. Kampen: Kok.

Pont, A D 1955. Nicolaas Jacobus van Warmelo 1835-1892. Utrecht: Kemink \& Zoron.

-.- 1970. Die vermindering van die ledetal van die Algemene Kerkvergadering. HTS 26, 118-145. 
Pont, A D 1977. Skrif en Kerkorde - enkele opmerkings. HTS 33, 77-90.

-.- 1978. Waar begin en waar eindig die amp. HTS 34, 48-59.

- 1981. Die historiese agtergronde van ons kerklike reg. Deel 1. Pretoria: HAUM.

-- 1982a. Kerk en struktuur. HTS 38, 1-22.

-- 1982b. Die betekenis van die meerdere vergaderinge ten opsigte van hulle gesag, funksie en handelinge in die kerk. HTS 38, 104-145.

Pont, A D, Botha, S J, \& Storm, J M G 1986. Gedenkalbum 1886-1986. Pretoria: NHW Pers.

Reitsma, J \& Van Veen, S D 1892. Acta der provinciale en particuliere synode. Deel 1: Noord-Holland 1572-1608. Groningen: Wolters.

--- 1894. Acta der provinciale en particuliere synode. Deel 3: Zuid-Holland 15931620. Groningen: Wolters.

-- 1896. Acta der provinciale en particuliere synode. Deel 5: Zeeland 1579-1620 en Overijssel 1584-1620. Groningen: Wolters.

Van Wyk, B J 1989. Die presbiteriaal-sinodale kerkbegrip met besondere verwysing na die kerkwet van die Nederduitsch Hervormde Kerk van Afrika. DD-proefskrif, Universiteit van Pretoria. 